\title{
Challenges of Codification for the International Law Commission in a Changing Landscape of International Law
}

\author{
Hajer Gueldich
}

As is well-known, efforts to systematically codify and develop international law have a long tradition, starting with Jeremy Bentham in $1789,{ }^{1}$ and continued by numerous academic institutions, conferences and committees. ${ }^{2}$ The founders of the United Nations, in 1945, mandated the General Assembly to "initiate studies and make recommendations for the purpose [...] of encouraging the progressive development of international law and its codification". 3 Two years later, the General Assembly delegated this task to a body of independent experts, the International Law Commission. ${ }^{4}$ Today, this Commission can look back on - and continues to produce - an impressive body of work, covering most areas of international law.

It is only natural that the Commission's work would evolve with the legal system it operates in. Over the past 70 years, international law has undergone fundamental changes: it accommodated the tension of the Cold War, the emergence of newly independent States, and the establishment of a global economic order. Since the end of the 2oth century, there has been an unprecedented expansion of international law, with a focus on international organizations, human rights, and the environment. The International Law Commission has adapted to these changes, for example by increasingly venturing into specialized areas of international law ${ }^{5}$ and elaborating "soft" instruments rather than draft treaties. ${ }^{6}$

1 Jeremy Bentham, The Works of Jeremy Bentham, vol 2 (William Tait 1843) 537.

2 For an overview of the historic development of codification efforts see the contribution by Keun-Gwan Lee in this Section.

3 Article 13, paragraph 1 (a) of the Charter.

4 UNGA Res 174 (II) (21 November 1947). By the same resolution, the General assembly adopted the statute of the ILC, which has subsequently been amended by UNGA Res 485 (V) (12 December 1950); Unga Res 984(x) (3 December 1955); Unga Res 985(x) (3 December 1955) and UNGA Res $36 / 39$ (18 November 1981).

5 The topics "Protection of the environment in relation to armed conflicts" and "Protection of the atmosphere" are examples from the field of international environmental law.

6 Recent examples include the "draft conclusions" on subsequent agreements and subsequent practice in relation to the interpretation of treaties (UNGA Res 73/202 (10 December 
To maintain its authority, the International Law Commission must continue to review the impact of a constantly changing legal environment on its work. Such assessment first requires a brief overview of the contemporary landscape of international law: the new challenges which form the context of the Commission's future work (II). Based on these observations, important future topics for codification can be considered (III). In addition, these challenges have implications for the Commission's methods of work (IV). Finally, it is possible to venture some conclusions and recommendations for a successful future of the International Law Commission in a challenging landscape of international law (v).

Codification may seem a technical operation, but in reality it has to mediate clashes of State interest, changing geopolitical conditions and a variety of legal traditions. As Charles de Visscher put it, codification is a progressive operation, ${ }^{7}$ which requires balancing the continuity of international law with the need to change and innovate the rules and structures of the international legal system to respond to new challenges. ${ }^{8}$

The challenges facing the Commission in the twenty-first century may be symbolized by the events on 11 September 2001, which effectively marked the start of the new millennium. Since then, the international community has struggled with increasingly complex security challenges and an evolving interpretation on the prohibition on the use of force. A growing number of humanitarian crises and disasters require an effective global response. Meanwhile, States are confronted with other players in the international sphere: international relations are increasingly shaped by the acts of non-state actors, from non-governmental organizations and multinational corporations to private military companies and terrorist groups. Furthermore, advances in information technology, from big data to social media, require coordinated regulatory action to protect the world from novel threats such as cyber crime or even

2018)) and identification of customary international law (UNGA Res 73/203 (20 December 2018)).

7 Charles De Visscher, 'La codification du droit international' (1925) 6 RdC 325, 397.

8 See further Hajer Gueldich, 'La mission des Nations Unies quant à la codification et au développement progressif du droit international au niveau régional' (2015) 2 Journal of the African Union Commission on International Law 296. 
cyber war. Perhaps less visible, though not less serious, are the growth of global inequalities between and within states and the waning enthusiasm for multilateral engagement.

It would be naive to assume that the Commission could turn the tide of global affairs by itself and fundamentally change the parameters of contemporary international relations. Nevertheless, the Commission cannot ignore the context in which its outcomes are received, interpreted and applied. By carefully selecting the topics on its programme of work, as well as by adapting its working methods to changing circumstances, the Commission may continue to provide the normative guidance it has offered in the past 70 years.

\section{The Substance: Current Trends and New Topics to Codify}

Identifying topics suitable for codification by the International Law Commission remains a complex exercise. It is one of the central characteristics of the International Law Commission that its field of work comprises international law in its entirety, even extending to private international law. ${ }^{9}$ Not without reason has the idea that the Commission could prepare a comprehensive code of international law been abandoned shortly after its inception. ${ }^{10}$ In light of the expansion international law has experienced over the last decades, such an endeavour has certainly not become any more feasible. Taking stock of the Commission's work, it is nevertheless remarkable that few areas of international law have remained untouched. So far, the Commission contributed to such diverse fields as the law of the sea, diplomatic relations, the responsibility of States and international organizations, international criminal law, the protection of the atmosphere, extradition and many other topics.

This illustrative - and heterogenous - list raises the question which substantive criteria govern inclusion of a topic in the Commission's programme of work. The statute of the Commission offers only limited guidance in that regard. The General Assembly and certain other bodies may set subjective priorities through special requests for codification ${ }^{11}$ or proposals for progressive

9 Article 1(2) of the ILC statute.

10 When the International Law Commission was established, a lively debate took place whether it should elaborate a comprehensive code of international law or work on individual topics. The latter approach prevailed. See Keun-Gwan Lee (n 2).

See article 18(3) of the ILC statute. 
development of international law. ${ }^{12}$ On its own initiative, the Commission may consider any topic it deems "necessary and desirable" for codification. ${ }^{13}$

Through its practice, the Commission has clarified the criteria for topics to be included in its programme of work:

(a) The topic should reflect the needs of States in respect of the progressive development and codification of international law;

(b) The topic should be sufficiently advanced in stage in terms of State practice to permit progressive development and codification;

(c) The topic is concrete and feasible for progressive development and cod-

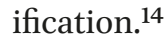

The Commission further emphasized that it "should not restrict itself to traditional topics, but could also consider those that reflect new developments in international law and pressing concerns of the international community as a whole." 15

It is especially this latter aspect which the Commission should not disregard as it approaches its eighth decade. As outlined above, there are several "pressing concerns" which international law needs to address. In particular, the Commission may consider examining in the future the areas of international security and the use of force (A); humanitarian response to conflicts and disasters (B); non-State entities in international law (C); and new technologies, cyber war and cyber criminality (D).

These suggestions may perhaps seem not "feasible" or not "sufficiently advanced in stage in terms of State practice to permit progressive development and codification". Indeed, the topics proposed here are not elaborate enough to resemble a concrete proposal for the Commission's agenda. ${ }^{16}$ Nevertheless, they certainly reflect "new developments in international law and pressing concerns of the international community as a whole" and would benefit greatly from the clarity and certainty that the Commission's work can provide. Naturally, the fields in which legal certainty is most necessary also tend to be

\footnotetext{
12 See articles 16(1), 17(1) and 18(3) of the ILC statute. For further discussion see below.

13 Ibid article 18(2).

14 ILC, 'Report of the International Law Commission on the work of its forty-ninth session' [1997] II (2) ILC Ybk 1, 72 at para 238.

15 Ibid.

16 When a topic is added to the Commission's long-term programme of work, a detailed proposal outlining the scope of the topic and plan of work is annexed to the Commission's annual report. See, for example, the proposals for the topics "Universal jurisdiction" and "Sea-level rise in relation to international law" annexed to the "Report of the International Law Commission on the work of its seventieth session' (2018) UN Doc A/73/10, 307 and 326 , respectively.
} 
particularly controversial and politically sensitive. The Commission must strike a delicate balance between political realities and the aspirations of the broader international community, ${ }^{17}$ but it should not shy away from making meaningful contributions in the most pressing areas of international law. Codification has never been understood as a static exercise. Echoing De Visscher's notion of a "progressive operation", Roberto Ago noted that "to codify the law has always meant modifying it partially, and sometimes even profoundly". ${ }^{18}$ The fact that certain questions of international affairs remain unregulated does not mean they are not susceptible to the grasp of international law. After all, the process of codification and progressive development of international law focuses specifically on those issues "not yet been regulated by international law or in regard to which the law has not yet been sufficiently developed in the practice of States". ${ }^{19}$ To paraphrase the International Court of Justice, "in situations in which political considerations are prominent it may be particularly necessary $[\ldots]$ to obtain [guidance on] the legal principles applicable". ${ }^{20}$ The Commission's work may help to clarify the current state of the law and give a neutral impetus for necessary progressive development from a "technical" perspective.

\section{A International Security and Use of Force}

The general prohibition of the use of force is one of the cornerstones of the international legal order. However, the system of exceptions to this prohibition established by the Charter of the United Nations in 1945 has proven illequipped to deal with new challenges for international security. Following a traditional interpretation of the Charter, legitimate use of force is limited to inter-State self-defence ${ }^{21}$ and Security Council authorization..$^{22}$ Given the well-known deadlock in the Security Council precipitated by the right to veto,

17 Sompong Sucharitkul, 'The role of the ILC in the decade of International Law' (1990) 3 LJIL15, 40.

18 See Roberto Ago, 'La codification du droit international et les problèmes de sa réalisation' in Maurice Batteli and others (eds), Recueil d'études de droit international en hommage à Paul Guggenheim (Imprimerie de la Tribune de Genève 1968) 94. Translation by the author.

19 Article 15 of the Commission's statue. See also A Mahiou, 'Le paradigme de la codification' in SFDI, La codification en droit international (Pedone 1999).

20 Interpretation of the Agreement of 25 March 1951 between the WHO and Egypt (Advisory Opinion) [1988] ICJ Rep 73, 87.

21 Article 51 of the Charter of the United Nations. See also Military and Paramilitary Activities in and against Nicaragua (Nicaragua $v$ United States) (Merits) [1986] ICJ Rep 14, para 195; Legal Consequences of the Construction of a Wall in the Occupied Palestinian Territory (Advisory Opinion) [2004] ICJ Rep 136, para 139.

Article 42 of the Charter of the United Nations. 
States have resorted to unilateral uses of force in legal grey areas to address the security challenges of today. Two issues stand out: invocation of the right of self-defence to combat international terrorism and humanitarian intervention to prevent atrocities during internal conflicts. While the motivation for both approaches is understandable, the absence of clear legal boundaries lends itself to politicization, double-standards and abuse, ultimately undermining the stability of international relations and the rule of law.

The International Law Commission may contribute to clarifying and developing the law in this respect. It may, on one hand, rein in excessive interpretations of the established exceptions to the prohibition of the use of force by restating their boundaries. On the other hand, the Commission may contribute to progressive development in this area by transcending the inter-State paradigm, emphasizing the protection of the individual as the ultimate objective of international law. To this end, the Commission could, for example, build on the work of the Evans/Sahnoun Commission of $22^{001}{ }^{23}$ and elaborate a draft convention on the responsibility to protect.

\section{B Humanitarian Response to Conflicts and Disasters}

Somewhat interlinked with the "responsibility to protect" is the broader field of humanitarian responses to conflicts and disasters. The International Law Commission has recently made an important contribution in this area when it completed the draft articles on protection of persons in the event of disasters. ${ }^{24}$ Building on this work, it may want to focus its attention on the pressing issue of internally displaced persons. Millions of persons remain displaced, yet apart from the Kampala Convention of $2009^{25}$ - which is restricted to Africa - there is so far no international legal instrument addressing this topic. A universal convention prepared by the International Law Commission could thus be a significant step forward in this area.

\section{Non-State Entities in International Law}

The increased presence of non-State actors in international relations touches on the very foundations of the international legal system. Prominent examples

23 Gareth Evans and others, Report of the International Commission on Intervention and State Sovereignty (International Development Research Centre 20o1).

24 ILC, 'Draft articles on the protection of persons in the event of disasters' (2016) UN Doc A/ 71/10, 13 .

25 African Union Convention for the Protection and Assistance of Internally Displaced Persons in Africa, adopted 23 October 20o9, entry into force 6 December 2012, UNTS registration no $5^{2375}$. 
include non-governmental organizations influencing diplomatic processes and operating actively "on the ground", multinational corporations shaping economies and affecting the realization of human rights, and insurgents or private military companies fighting in armed conflicts. Recalling the resounding success of the International Law Commission's work on fundamental topics such as the law of treaties and State responsibility, it seems well-positioned to address the questions arising from these developments.

Some aspects still need time to develop before they are suitable for treatment by the International Law Commission. Integrating non-state actors into the framework of the law of treaties and international responsibility, for example, has received attention in academia, ${ }^{26}$ but has yet to take hold in legal practice. These issues should nevertheless be part of a long-term vision for the Commission's work. It will not be too long before (after States and international organizations) a third generation of treaties, involving non-governmental organizations will catch the imagination of the international community. The fourth generation would soon also be in sight, covering treaty relations or international agreements where international or multinational enterprises are contracting parties. Such new conventions will also trigger questions over the international responsibility of non-state actors, which should be clarified.

Some concrete phenomena seem suitable for treatment by the Commission in the shorter term. One example may be the use of private military companies during or after armed conflicts, an issue that touches upon the law of State responsibility, humanitarian law and human rights law. ${ }^{27}$ Here,

26 See Cedric Ryngaert, 'Non-State Actors in International Law: A Rejoinder to Professor Thirlway' (2017) 64 NILR 155; Edda Kristjansdottir, Andre Nollkaemper and Cedric Ryngaert, International Law in Domestic Courts: Rule of Law Reform in Post-Conflict States (Intersentia 2012); Nicolas Carrillo Santarelli, 'Non-State Actors Human Rights Obligations and Responsibilities under International Law' (2008) Revista Electronica De Estudios Internacionales 1; Janne Nijman, 'Non-State Actors and the International Rule of Law: Revisiting the "Realist Theory" of International Legal Personality' in Math Noortman and Cedric Ryngaert (eds), Non-State Actor Dynamics in International Law: From LawTakers to Law-Makers (Ashgate 2010); Math Noortman, August Reinisch and Cedric Ryngaert (eds), Non-State Actors in International Law (Hart 2015); and Noemi Gal-Or, Cedric Ryngaert and Math Noortman (eds), Responsibilities of the Non-State Actor in Armed Conflict and the Market Place (Brill 2015).

27 See Peter Benicsák, 'Advantages and disadvantages of private military companies' (Univerzita Obrany V Brně, Economics and Management 2012); Erika Calazans, Private military and security companies: The implications under international law of doing business in war (Cambridge Scholars 2016); Lindsey Cameron and Vincent Chetail, Privatizing War: Private Military and Security Companies under Public International Law (CUP 2013); Lindsey Cameron, The privatization of peacekeeping: Exploring limits and responsibility 
the Commission could clarify the obligations of States which employ such companies and develop a framework for responsibility of the companies themselves.

\section{New Technologies, Cyber War and Cyber Criminality}

The digitalization of ever more parts of our lives has not left international relations untouched. The internet may be - and allegedly has been - used by States and non-State actors to attack infrastructure or spread misinformation and propaganda. "Cyber crime" or "cyber warfare" are further concerns whose global nature requires a global response. With intergovernmental negotiations on cyber-related legal issues currently stalling, ${ }^{28}$ the International Law Commission could make a useful contribution by clarifying the applicability of established norms, such as the principle of non-intervention, in the digital realm. The technical complexity of this area should not dissuade the Commission from addressing it, as it may consult scientific experts to supplement its efforts. ${ }^{29}$

Apart from adapting the substance of its work, the changing conditions of international affairs must also be reflected in the working methods of the Commission. Increased technical complexity of specialized fields of international law is one, but certainly not the only, challenge in this regard. To retain its relevance, the Commission must step out of its own circle of legal experts and engage with the international community - in the broadest sense of the term - to effectively fulfil its mandate.

under international law (CUP 2017); William Feldmann, Privatizing war: A moral theory (war, conflict and ethics) (Routledge 2016); Thierry Garcia, Les entreprises militaires et de sécurité privées appréhendées par le droit (Mare \& Martin 2017); Robert Mandel, Armies without States: The privatization of security (Lynne Reinner 2002); Hannah Tokin, State control over private military and security companies in armed conflict (CUP 2011); Nikolaos Tzifakis, Contracting out to private military and security companies (Centre for European Studies 2012); Al Venter, War Dog: Fighting Other People's Wars: The Modern Mercenary in Combat (Casemate 2005); and Peter W Singer, Corporate Warriors: The Rise of the Private Military Industry (Cornell UP 2003).

28 See e.g. Adam Segal, "The Development of Cyber Norms at the United Nations Ends in Deadlock. Now What?' (Council on Foreign Relations, 29June 2017) <https://www.cfr.org/ blog/development-cyber-norms-united-nations-ends-deadlock-now-what>. See article $16(\mathrm{e})$ of the ILC statute. 


\section{A Selection of Topics}

This increased engagement must start at the beginning of the Commission's work, the selection of topics. According to the Commission's statute, proposals for progressive development of international law may be made by the General Assembly, Members of the United Nations, other principal organs of the United Nations, specialized agencies, or official bodies established by intergovernmental agreement to encourage the progressive development of international law and its codification. ${ }^{30}$ While it seems that there are plenty of avenues to entrust the Commission with tasks, assignments by the General Assembly let alone proposals from other entities - have been the exception throughout the work of the International Law Commission. ${ }^{31}$ Encouraging stronger participation of other United Nations entities in the selection of topics should be a priority for the Commission to increase the relevance of its work. Although not envisaged by its statute, the Commission may even wish to consider including the suggestions of non-governmental organizations in the topic-selection process.

\section{B Dissemination of International Law}

It is important to increase dissemination of international law including through teaching, research, publication and translation of instruments. The Commission already actively contributes to this mission through lending its participation to the International Law Seminar, which takes place annually during the Commission's session in Geneva. Participants in the Seminar attend public meetings of the Commission, as well as lectures and briefings delivered by its members and representatives of other organizations based in Geneva. ${ }^{32}$

In addition, the Codification Division of the United Nations Office of Legal Affairs, which serves as the secretariat of the Commission, facilitates regular training courses in international law at the regional and international level through the Programme of Assistance in the Teaching, Study, Dissemination and Wider Appreciation of International Law. ${ }^{33}$

In terms of research, publication and translation of instruments, the Commission's Yearbook offers an authoritative account of its meetings and their outcomes. The Yearbook is published in all official United Nations languages, even though sometimes with a little delay. Moreover, the website of the

$30 \quad$ Ibid articles 16(1) and 17(1).

31 United Nations, The Work of the International Law Commission, vol I (gth edn, United Nations 2017) 34-47.

32 See $<$ https://ilsgeneva.ch/>.

33 See $<$ http://legal.un.org/poa/index.html $>$. 
Commission offers a comprehensive Analytical Guide, with links to all publicly available documents relating to the Commission's work.

Nevertheless, there is always a need for more national, regional, and international workshops on the implementation of international law, in order to pursue legal developments in the general interest and for the common benefit of mankind.

\section{Increased Engagement with Developing States}

To combat the increasing global inequalities in political power and legal expertise, the Commission should increase its engagement with developing States. Increasing awareness of international law in developing countries and allowing them to contribute to its formation would counter impressions of international law as a one-sided system serving only the interests of a particular set of powerful States. Such cooperation would require developing countries to actively promote international law in academic curricula and judicial practice, and to provide opportunities for lawyers to participate globally in research and the practice of international law.

\section{Cooperation with Other Institutions and Academics}

The Commission's statute allows formal consultations with organs of the United Nations, official or non-official international or national organizations, and with scientific institutions and individual experts. ${ }^{34}$ Article 26, paragraph 4, of the Commission's statute highlights the importance of consultation with "intergovernmental organizations whose task is the codification of international law".

The International Law Commission already cooperates with a number of regional institutions promoting international law, namely the African Union Commission on International Law, the Asian-African Legal Consultative Organization, the Inter-American Juridical Committee and the Council of Europe's Committee on Legal Cooperation and Committee of Legal Advisers on Public International Law. ${ }^{35}$ Intensifying these relationships has been endorsed by the Commission for a long time. ${ }^{36}$ Considering the growing importance of regional arrangements in international law, this endeavour can only be welcomed. An alternative to a largely formalized exchange of views between representatives of these bodies would be to hold joint sessions and collaborate on certain

\footnotetext{
34 See articles 16(e), 25(1) and 26(1) of the ILC statute.

35 United Nations (n 31) 84-85.

36 See ILC, 'Report of the International Law Commission on the work of its forty-eighth session' [1996] II(2) ILC Ybk 97 at para 239-240.
} 
topics. ${ }^{37}$ Such close cooperation may provide mutual inspiration and help avoid redundancies.

In addition, a stronger relationship with academia and civil society may prove beneficial for the International Law Commission. While events such as the commemoration of the Commission's anniversaries provide an opportunity for organized academic exchange, ${ }^{38}$ a more sustained exchange of views may help the Commission staying abreast of new trends and developments.

\section{Conclusion}

Throughout these 70 years, the International Law Commission has stood the test of time. It has done much to clarify the rules of international law on topics which are of the greatest importance in a very wide range of areas. As indicated above, the codification and progressive development of international law is a continuous and progressive process, not a static one. Since its establishment, the Commission has been the main driver of and point of reference for this process. As has been observed by a former member of the Commission, "[1]ike most other things associated with human imperfections, the work of the Commission is not infallible, nor beyond improvement. On the contrary, the law itself is not static. It is changing with a dynamic force. And so must be the Commission ..." 39

Several concrete recommendations have been made for the Commission to retain its relevance in challenging time. Two general lessons can be drawn. First, to effectively deal with the "pressing concerns of the international community as a whole", the Commission must diversify - not only the topics on its programme of work, but also the dissemination of its outcomes, the way it brings in external expertise and viewpoints from developing States, and its interaction with other bodies, from regional organizations to academia (not to speak of diversity in the composition of its membership, a very valid point made by others in this publication).

37 Ibid, suggesting the possibility of joint studies on particular legal topics.

38 See United Nations (ed), Making Better International Law: The International Law Commission at 50, Proceedings of the United Nations Colloquium on Progressive Development and Codification of International Law (United Nations 1998) and United Nations, The International Law Commission Fifty Years After: An Evaluation (United Nations 2000).

39 Sucharitkul (n 17) 37. 
Second, the Commission should not shy away from dealing with some of the most complicated dilemmas in international relations today. Questions over the use of force, self-defence, humanitarian action, the role of non-State actors and cyber threats clearly have a political character, but there is always a legal angle to be found. The lack of leadership on these issues by prominent political bodies, in particular the Security Council, compels other institutions to step in. As a subsidiary body of the General Assembly, composed of eminent academics and practitioners in international law, the International Law Commission can lend its expertise, if not to solve current challenges, then at least to promote a common language - the language of international law - in which to constructively debate how to deal with them. This is a significant responsibility, but one that the Commission in the past 70 years has demonstrated to be able to bear. By reducing the gap between the legal and the political, the Commission can make a practical contribution to a world that is more secure, more peaceful, and more just. 